\title{
Northern Vanuatu as a Pacific Crossroads: The Archaeology of Discovery, Interaction, and the Emergence of the "Ethnographic Present"
}

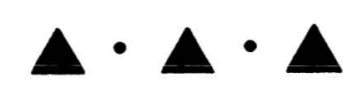

STUART BEDFORD AND MATTHEW SPRIGGS

\section{INTRODUCTION}

Northern VANUATU (Fig. 1) is located in a strategic region of the Western Pacific, to the south of the Solomons, north of New Caledonia and west of Fiji and Polynesia. It may have acted as a crossroads between these other archipelagoes from the time of initial human colonization some 3000 years ago and through the succeeding millennia. The authors are currently directing an Australian Research Council-funded project that addresses research issues associated with initial human colonization and subsequent cultural transformations in the region. It focuses on inter-archipelagic interactions ${ }^{1}$ with island groups to the north and east-primarily the Solomon Islands and Fiji-and their role in the development of the oft-remarked-upon cultural diversity of northern Vanuatu. There is broad unity at one level in language and in the institution of grade-taking, raising of full-circle tusker pigs, and the use of kava, but at the same time a considerable diversity in the manifestations of all these phenomena and in particular in the number of languages, in the plastic arts, and in the detail of social structure and architecture (Bonnemaison et al. 1996).

The accounts of the early European explorers and later works by pioneering anthropologists have in many respects shaped the perceptions, constructs, and context that continue to influence contemporary researchers in Pacific Studies, including archaeologists (Clark 2003). Pioneering anthropologists in Vanuatu such as Deacon (1934) and Layard (1942) both explained northern Vanuatu cultural diversity as resulting from four separate migrations, the last introducing the graded society. Although multiple migrations as an explanation for the distribution of particular cultural traits or trait complexes has very much gone out of intellectual fashion since then, what has replaced it is either an over-generalized appeal to local innovation to explain all cultural differences since initial settle-

Stuart Bedford is Research Fellow, Department of Archaeology and Natural History, Research School of Pacific and Asian Studies, Australian National University; Matthew Spriggs is Professor in the School of Archaeology and Anthropology, College of Arts and Social Sciences, Australian National University. 


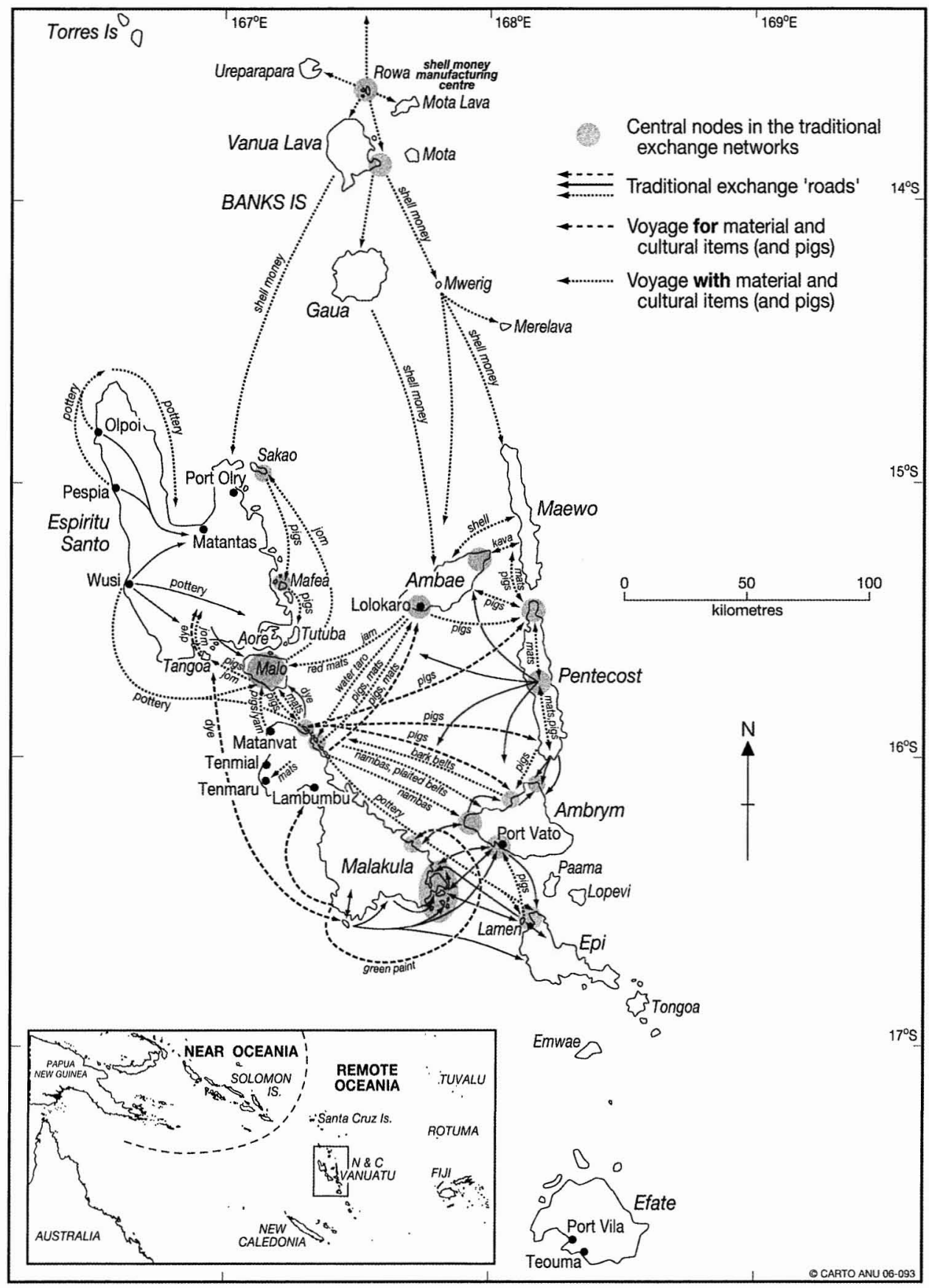

Fig. 1. The northern and central parts of Vanuatu, showing traditional exchange "roads" as reconstructed from ethnohistory. Links to the south of Epi Island and those involving the Torres Islands are not shown. Jom is a type of shell money produced on the island of Malo, and nambas are penis wrappers. Map adapted from Huffman (1996). 
ment, or a retreat from any theorization of diversity at all. We believe that it is time to return again to serious consideration of this diversity and the theoretical arguments that have been used to explain it.

Modern archaeology began in the Pacific in the late 1940s and it was quickly demonstrated that there was considerable time depth associated with human occupation of the Western Pacific, well beyond that considered by these early theorists (Kirch 2000). It is now realized that the "ethnographic present" contains a whole series of cultural snapshots which may or may not be associated with any great time depth, and which have been heavily transformed by European contact (Spriggs 2005).

Archaeological research over the last five decades has established that human colonization of Island Melanesia (defined as the Bismarck Archipelago, Solomon Islands, Vanuatu, and New Caledonia) began in excess of 40,000 years ago (Leavesley and Chappell 2004; Spriggs 1997a) and during the Pleistocene probably progressed as far as the end of the main Solomons chain along a series of intervisible islands forming what is often called Near Oceania (Green 1991). Further movement eastward out into Remote Oceania, a region with substantially larger water gaps separating often-smaller islands, did not begin until just over 3000 years ago.

Once human settlement beyond the main Solomons did occur it appears to have been very rapid, with people of the Lapita culture colonizing eastward through the Southeast Solomons, Vanuatu, New Caledonia, and Fiji as far as Tonga and Samoa over a period of only a few hundred years (Kirch 1997; Spriggs 1997a). Their proximate origin was in the Bismarck Archipelago where a melding of disparate cultural elements had taken place to form the Lapita cultural complex (Green 2000; Spriggs 2003).

The reign of Lapita however, at least as an archaeologically distinct horizon defined by its dentate-decorated pottery, was relatively short-lived. It has been demonstrated that in Remote Oceania it generally lasted only 200-300 years (Anderson and Clark 1999; Bedford 2003; Burley et al. 1999; Sand 1997). It is from about 2700 years ago that clear divergence in the archaeological record begins, suggesting a contraction or specialization of exchange, an increasing focus on local adaptation, sociopolitical transformation, and possibly secondary migrations by groups with a quite different cultural background (Spriggs 1997a:152161). However, despite the fact that the period after Lapita through to the present represents 90 percent of the human history of western Remote Oceania, this time span remains, with a handful of exceptions, poorly defined and under-researched archaeologically in Island Melanesia beyond the Bismarck Archipelago (Kirch 2000: 117-164; Walter and Sheppard 2006:137-144).

Considerable effort has been invested in tracing the historical development of exchange systems, communicative networks, and the dynamics of cultural change in Near Oceania and in Fiji and West and East Polynesia, but there remains a large and crucial under-researched gap in northern Vanuatu in western Remote Oceania, and an equally significant one in the more southeasterly parts of the main Solomons chain in Near Oceania.

Fundamental research questions that can be addressed in the northern Vanuatu area through archaeological methods include the timing and scale of cultural diversification, and the dynamics and nature of culture change. Two elementary 
and certainly interrelated drivers have led to the ethnographic mélange in the region: innovation on the one hand, and acquisition through interaction, contactinduced change, or direct migration on the other. It is the interplay of these that the project has sought to address, rather than assuming one of them as the dominant process.

There is empirical archaeological evidence, from initial Lapita settlement through to the recent past that attests to phases of inter-archipelagic interaction in western Remote Oceania. At the beginning of the current project, evidence associated with Vanuatu included pottery on Santo, Malo, and Erromango brought from New Caledonia (Dickinson 2001) and obsidian from the Bismarck Archipelago found on Malo in the Lapita period (Ambrose 1976). Later periods of interaction are evidenced by Banks Islands obsidian found in Fiji (Best 1987), and in Tikopia (Kirch and Yen 1982), and the Reefs-Santa Cruz Group in the Southeast Solomons (Ambrose 1976). A range of materials from the main Solomons and even farther north was imported across the Remote Oceania barrier into the Southeast Solomons in the Lapita and post-Lapita eras and may well have also reached Vanuatu (Green and Kirch 1997). For decades archaeologists have postulated similarities in the ceramics and other material culture of Vanuatu, Fiji, New Caledonia, the Solomons, and New Guinea (Golson 1961; Green 1963; Spriggs 1997a, 2004).

Despite its strategic location and high research potential much of northern Vanuatu remains an archaeological terra incognita and the confirmation or otherwise of inter-archipelago interaction, its chronology, influence, and intensity remain largely unresearched. The most detailed archaeology that has been carried out was undertaken by Ward (1979) on the small islet of Pakea in the Banks Islands. Several researchers have worked on Lapita sites on Malo (Hedrick n.d.; Hedrick and Shutler 1969; Galipaud 1998a; Noury 1998; Pineda and Galipaud 1998) and more recently on Aore, Tutuba, and Mafea (Galipaud 2001; Galipaud and Swete-Kelly 2005; Galipaud and Vienne 2005). Galipaud has also carried out a series of surveys and excavations on Santo, primarily on the west coast and in the Torres and Banks Islands (Galipaud 1996a, 1996b, 1998b). Further surface surveys are documented in unpublished reports by the Vanuatu Cultural and Historic Sites Survey (VCHSS).

\section{INITIAL RESEARCH HYPOTHESES}

At the start of the project we developed a series of primary interrelated hypotheses to be tested. They were as follows:

\section{Northern Vanuatu was a major stepping-stone during the initial human colonization and settlement of Remote Oceania}

Over the last few decades of research an increasingly robust theoretical framework and associated database outlining the chronology, spread, and socioeconomic nature of Lapita have begun to emerge. Conventionally it has been argued that there was a clinal west-east pattern of settlement with accompanying "distance decay" in ceramics (Kirch 1997), although more recently this pattern has been challenged with some authors arguing for the potential of multiple origins for 
particular Lapita communities (Burley and Dickinson 2001; Clark and Anderson 2001).

Debate continues to rage over a whole spectrum of issues associated with Lapita archaeology, in part because of very patchy distributional data for archipelagoes such as the Solomons and Vanuatu. Lying southeast of the Reefs-Santa Cruz Group with Tikopia and Vanikoro in between and $800 \mathrm{~km}$ west of Fiji, northern Vanuatu provided both an easy target and subsequent safety net for initial colonizers as they moved out from the main Solomons chain into the previously unexplored areas of the Pacific (Irwin 1992). Lapita sites had however only ever been reported in Vanuatu as far north as Malo and Aore off the southern tip of Santo prior to 2005, and have only been reported in limited detail. In 2002 and 2003 preliminary survey on the small islands off the northeast coast of Malakula showed that Lapita sites are there and they are extremely well preserved beneath multiple tephra layers (Bedford 2003, 2006b). The lack of any Lapita evidence in the north was considered by us to relate simply to a lack of targeted fieldwork in the area.

With this in mind the project targeted key areas to attempt to confirm the predicted widespread nature of Lapita settlement and focus on determining whether empirical evidence for inter-archipelagic interaction could be identified, either with 'homelands' to the west or new staging posts to the south or east.

\section{Post-Lapita interaction with the populations to the northwest was regular and influential}

One of the most important research questions regarding the prehistory of the Southwest Pacific is the nature of the cultural changes which occurred during the period after Lapita and that ultimately led to the conspicuous diversity that is found in the region. A widely accepted explanation for these cultural changes has been that they were related to a secondary wave of migration or at least extended contact from non-Austronesian populations farther north, contributing to the "Melanesianization" of the region as far east as Fiji (Golson 1961; Green 1963; Spriggs 1997a). It has been argued that the most visible manifestation archaeologically was to be found in the ceramic record, with some authors claiming that there is evidence of a Melanesia-wide Incised and Applied Relief (IAR) tradition which demonstrated synchronous change from the post-Lapita period onward (Galipaud 1996a; Spriggs 1997a; Wahome 1999).

More recently this view, or at least the evidence to support it, has been challenged (Bedford 2000, 2006a; Bedford and Clark 2001; Clark 2003), and the challenge has subsequently gained some support (Felgate 2003; Sheppard and Walter 2006). This was an ongoing debate in which the authors of this paper held opposing views and so have combined on this project to address this issue in a region that is core to the debate.

Clear links with the northwest are picked up again in the last 500 years or so in oral traditions, ethnographic observations, archaeological evidence, and other data (Mondragon 2003; Spriggs 2000). There are a number of specialized cultural practices noted by early ethnographers (Speiser 1996) that are unlikely to have developed independently but rather are likely indicators of some form of interaction or even migration. Examples are headbinding and the production of fullcircle pig tusks that are found both in northern Vanuatu and in southern New 
Britain in the Bismarck Archipelago. Green (1999) has combined archaeological, linguistic, and biological evidence to suggest that influence from Near Oceania in the form of sustained contact from or even migrations of non-Austronesianspeaking groups might well have contributed to substantial change in this part of Remote Oceania in the last 1000 years. Research in northern Vanuatu should help to clarify the evidence for temporality, extent, and influence of such contacts.

\section{Contact with Fiji to the east was intermittent but significant}

Both linguists (Geraghty 1983:389) and biological anthropologists (Visser 1994:249-250) have argued for contact and migration from Vanuatu to Fiji at various times in the past. The known distributions of the traditional drug kava (Piper methysticum) and of an introduced rat (Rattus praetor) have also been used to bolster this argument (Sand 2000), and the recovery of Banks Islands obsidian on Lakeba in eastern Fiji (Best 1987) provides strong evidence. It was generally accepted until recently that similarities in ceramic motifs, betokening contact, could also be demonstrated (Best 1984; Frost 1979). Previously claimed parallels in contemporary ceramics from the center and south of Vanuatu with those in Fiji have, however, now been strongly challenged (Bedford 2000, 2006a; Bedford and Clark 2001). Researchers arguing for ceramic connections have subsequently suggested that evidence for ceramic links will be found in northern Vanuatu once research on the relevant periods is carried out there (Best 2002:30-32). In the late part of the Fijian sequence large bullet-shaped pots are found, as they are in parts of northern Vanuatu in the same period (Bedford 2000, 2006a). Such evidence for Vanuatu-Fiji connections is suggestive although largely circumstantial in our present state of knowledge. The current project might be able to establish the frequency and significance of such contacts.

\section{Polynesian contacts with northern Vanuatu were rare and unimportant}

Evidence of substantial Polynesian influence within the last 1200 years has been demonstrated in central and southern Vanuatu (Garanger 1972; Luders 1996, 2001; Shutler and Shutler 1968; Shutler et al. 2002; Spriggs 1997a:207-218). This includes contact-induced changes in social structure, language, and artifact forms. On some "Polynesian Outlier" islands previous populations or at least their languages have been replaced entirely. There is much less general evidence of such influence and a lack of such Outlier islands in northern Vanuatu. This contrasts with the area immediately to the north in the Southeast Solomons, and to the south in central and southern Vanuatu. Northern Vanuatu is thus currently rather a void in the story of Polynesian influence on Island Melanesian societies.

It may be that Polynesian influences have been masked or replaced by recent sociopolitical developments and cultural practices associated with the spread of the grade-taking political system throughout northern Vanuatu (Bonnemaison 1996:200-216). This system could have replaced more Polynesian-influenced chiefly systems, such as those still present in the center and south of the archipelago, and attested on islands like Ambrym in the recent past (Tonkinson 
1968:27-28). Investigation of the history of the grade-taking system and its associated material culture will help to shed light on this issue. The possible influence of Polynesian contact on the development of northern Vanuatu cultures has not been the topic of archaeological investigation up to now.

\section{Patterns of cultural variation in northern Vanuatu as recorded ethnographically have developed only relatively recently' (last 500 years) and are in part a response to European} contact and colonization

Due to sustained efforts by a number of anthropologists, ethnologists, travelers and explorers, there are often-detailed records of the extant sociopolitical systems and culture of northern Vanuatu for the last century. These various "snapshots" provide a series of ethnographic endpoints from which to work back into the deeper past. The accounts describe dense exchange networks (see Fig. 1) related to an overarching grade-taking political system which manifested itself materially in diverse ways (sculpture, stone architecture, settlement layout, etc.). Concentrating on the major nodes of this exchange system and seeing how long their centrality has existed in its current form will help elucidate its time depth.

Preliminary archaeological research (Bedford 2000, 2006a) has established that there is similarity in the ceramics across a number of islands of northern Vanuatu dating to the last 500 years, an indication of some degree of cultural homogeneity. During the last 200 years or so, however, there appears to have been some breakdown of this communicative network at which time ceramic production either died out or became island-specific in style.

It is unlikely to be coincidental that this occurred during the period of European contact, beginning with Quiros' expedition of 1606. The Spaniards tried to establish the colony of New Jerusalem in Big Bay on Santo Island (Spriggs 1997a:223-240). The descriptions by expedition members suggest that the Big Bay area was heavily populated at the time (Kelly 1966). The Spanish attempt at settlement failed and there was a gap of 168 years before Captain James Cook returned to Big Bay. Of major importance in any consideration of the recent evolution of sociocultural patterns in the region is the impact of these very earliest European visits on the populations of various areas through introduced disease (Kirch 2000; Sand 1995). The historically recorded cultural patterns of the region cannot be understood without knowledge of recent population history beyond the period of sustained European contact. Big Bay, Santo can form one test case in this regard.

\section{APPROACH}

This was planned as the first large-scale archaeological project to consider northern Vanuatu as an analytical unit and thus address the culture history of a significant crossroads region of the Southwest Pacific from its initial human settlement some 3000 years ago, through to the recent past. It fills in a blank between better-researched areas of central and southern Vanuatu and New Caledonia to the south, Fiji to the east, and (for islands like Tikopia and the Reefs-Santa Cruz Group at least) the Southeast Solomons to the northwest. 
Our major theme of explaining the genesis of cultural diversity in the region, using the drivers of innovation and acquisition, gives the study a more general interest in archaeological theory building. Cultural change in the Pacific has long been seen as a recapitulation of the classic pattern of social evolution from tribe to chiefdom to state (Earle 1991, 1997; Goldman 1970; Sahlins 1958, 1963). Northern Vanuatu presents a very different picture which confounds such universal models of historical process, with a likely development from a simple chiefly structure at initial settlement through to an elaborate system of acquiring rank in the recent past through grade-taking ceremonies involving the sacrifice of specially reared pigs. This was a system that transcended language boundaries and individual islands to create webs of power between different areas, underwritten by elaborate patterns of inter-island exchange.

A predictive model of site location and preservation potential for northern Vanuatu was developed, based on three inter-linked factors: geological mapping, site location information from previous archaeological research, and ethnographic accounts describing various areas on particular islands that acted as nodes in a communicative network, both within Vanuatu (Huffman 1996:184 [see Fig. 1]) and oriented externally in relation to the Southeast Solomons (Kirch and Yen 1982). Past experience in Vanuatu has shown that sites with well-preserved lengthy cultural sequences are found in areas of recent uplift, especially when backed by older limestone formations.

Experience has also shown, for instance on Aneityum in southern Vanuatu (Spriggs 1981, 1997b), that site visibility is considerably reduced in areas of volcanic substrate with high erosion and deposition rates. Acid soils in these conditions are also a problem for the preservation of organic cultural materials over long time periods. Islands that are some distance from active volcanoes but close enough to receive regular showers of tephra can be particularly productive, however, especially where the major substrate is marine sands. Such a situation has been demonstrated on both Efate in central Vanuatu (Bedford and Spriggs 2000) and in northern and southern Malakula (Bedford 2003). Comparing the distribution of known sites with long sequences and/or preservation conditions to the geological conditions confirms that some areas in northern Vanuatu are much more prospective than others for our purposes.

Matching these factors against the major exchange nodes described above allowed us to target particular areas of high potential and to give lower priority to others. In addition, other geologically and archaeologically promising areas (albeit without identified recent exchange centrality) were identified. The hypotheses were to be specifically tested through extensive archaeological survey and targeted excavation to provide a more robust data set for the region from Lapita settlement through to the recent past. For the Lapita period this could then be compared with data from Fiji and the Southeast Solomons and, within Vanuatu, the previous research data from Malo, Aore, and Malakula, to determine the extent and nature of interaction with homelands to the west or new staging posts to the south or east. A key aspect in facilitating the testing of the frequency and chronology of interaction with the northwest and east over the millennia would be the establishment of detailed post-Lapita cultural sequences in the same fashion as has already been achieved in central and southern Vanuatu (Bedford 2000, 2006a; Bedford and Spriggs 2000). 


\section{RESULTS}

The results of the first two seasons of fieldwork are presented within the framework of the five hypotheses. At this stage they are very much in summary form as many of the sites have only been identified within the last six months and detailed analysis and write-up are continuing.

\section{Northern Vanuatu as a Major Lapita Stepping-Stone}

Lapita sites in Vanuatu have until very recently been notoriously difficult to locate due primarily to ongoing and sometimes cataclysmic volcanic and tectonic activity across the archipelago (Anderson et al. 2001; Bedford 2003, in press; Bedford and Spriggs in prep.). The recent discovery, however, of the very well-preserved sites of Makue on Aore (Galipaud 2001; Galipaud and Swete-Kelly 2005; Galipaud and Vienne 2005), sites on the small islands off the northeast coast of Malakula (Bedford 2003), and Teouma on the south coast of Efate in central Vanuatu (Bedford et al. 2004) have dramatically increased our knowledge in regards to Lapita in Vanuatu and the wider region.

Teouma was discovered immediately after final preparation of our grant application to the ARC at the beginning of 2004 (Bedford et al. 2004), but subsequent excavations in mid-2004 directed by the authors revealed it to be a major Lapita cemetery and slightly later habitation site and indications are that it is associated with initial colonization of central Vanuatu (Bedford et al. 2006). Despite the fact that Teouma is somewhat to the south of the area of our primary concern, the substantive data that have been gleaned from the site are particularly well suited to addressing Hypothesis One in relation to the stepping-stone status of Vanuatu during the Lapita expansion.

First, the widespread nature of Lapita settlement in Vanuatu is now being confirmed. It can be comfortably predicted that Lapita sites will be found on most islands of the archipelago, barring those whose form has been radically altered since Lapita settlement by volcanic activity (e.g., Ambrym, Ambae), and where only major industrial earthmoving might produce a chance discovery. Lapita sites with a component of dentate-stamping now include those on the island of Erromango (2 sites) in the south, Efate (2) in the center, in northern Vanuatu on both the large and small islands of Malakula (5) and on Malo (6), Aore (2+), Tutuba (2), and Mafea Islands (2) off the south and southeast coast of Santo.

Fieldwork undertaken by the authors in September 2006 revealed two Lapita sites in the north of the main island of Santo, the largest island in Vanuatu (3900 $\mathrm{km}^{2}$ ). One is located at Matantas village in the southeast corner of Big Bay, and another with stylistically identical plainware and shell-impressed ceramics recovered from a single $1 \times 1 \mathrm{~m}$ test-pit is located at Port Olry on the northeast coast of Santo. Preliminary dating (although lacking precision due to a flat part of the calibration curve) and initial assessment of the ceramics from the sites indicates that they are associated with the late Lapita period in Vanuatu around 27902350 cal. B.P. (Table 1). These sites are thus far the northernmost Lapita sites identified in Vanuatu and the first for mainland Santo. While Lapita sites have yet to be identified in the Banks or Torres Islands in the far north of Vanuatu, the distribution of Banks Islands obsidian in a number of Lapita sites farther south in 
Table i. Selected Radiocarbon Dates from Northern Vanuatu, 2005-2006

\begin{tabular}{|c|c|c|c|c|c|}
\hline $\mathrm{SITE} / \mathrm{DEPTH}$ & $\begin{array}{l}\text { LABORATORY } \\
\text { NUMBER }\end{array}$ & $\mathrm{C}^{14} \mathrm{AGE}$ & $\begin{array}{c}\mathrm{D}^{13} \mathrm{C} \\
( \pm 0.02 \%)\end{array}$ & MATERIAL & CALIBRATED AGE B.P. (2S.D., 95.4\%) \\
\hline Port Olry, Santo $20-40 \mathrm{~cm}$ & Wk-20571 & $2519 \pm 37$ & -22.2 & Coconut shell & $2720-2630(24.9 \%), \mathbf{2 6 2 0 - 2 3 6 0}(70.5 \%)$ \\
\hline Port Olry, Santo $40-60 \mathrm{~cm}$ & Wk-20570 & $2494 \pm 35$ & -26.5 & Charcoal & $2710-2560(11.6 \%), \mathbf{2 5 5 0 - 2 3 5 0}(62.7 \%)$ \\
\hline Port Olry, Santo $1.10 \mathrm{~cm}$ & Wk-20003 & $2989 \pm 49$ & -23.3 & Nut shell & $3270-2920(95.4 \%)$ \\
\hline Port Olry, Santo $130-150 \mathrm{~cm}$ & Wk-20004 & $2557 \pm 48$ & -27.6 & Nut shell & $2750-2430$ (89.8\%), 2420-2360 (5.6\%) \\
\hline Matantas, Santo TP17 $110-130 \mathrm{~cm}$ & Wk-20005 & $2634 \pm 48$ & -23.4 & Nut shell & $2790-2470(95.4 \%)$ \\
\hline Matantas, Santo TP $1860-70 \mathrm{~cm}$ & Wk-20006 & $2588 \pm 48$ & -23.1 & Nut shell & $2760-2450$ (93.6\%), 2390-2360 (1.8\%) \\
\hline Mafilau, Epi I. $50 \mathrm{~cm}$ & Wk-18009 & $2493 \pm 33$ & -23.9 & Coconut shell & $2740-2450(93.6 \%), 2390-2360(1.8 \%)$ \\
\hline Mafilau $100 \mathrm{~cm}$ & Wk-18010 & $2486 \pm 32$ & -24.2 & Charcoal & $2730-2430$ (91.8\%), 2420-2360 (3.6\%) \\
\hline Mafilau $200-210 \mathrm{~cm}$ & Wk-19649 & $2465 \pm 31$ & -23.9 & Nut shell & $\begin{array}{l}2700-2630(14.5 \%), 2620-2590(4.0 \%), \\
2550-2340(76.8 \%)\end{array}$ \\
\hline Mafilau $290-300 \mathrm{~cm}$ & Wk-19650 & $2592 \pm 32$ & -24.8 & Nut shell & $2750-2480(95.4 \%)$ \\
\hline Mafilau $440-450 \mathrm{~cm}$ & Wk-19651 & $2556 \pm 31$ & -23.1 & Charcoal & $2740-2450$ (93.4\%), 2390-2360 (2.0\%) \\
\hline Ambek, Vanua Lava I. $20-40 \mathrm{~cm}$ & Wk-19647 & $374 \pm 30$ & -27.9 & Nut shell & 490-310 (95.4\%) \\
\hline Ambek $70-90 \mathrm{~cm}$ & Wk-19648 & $390 \pm 31$ & -24.9 & Nut shell & $\mathbf{5 0 0 - 3 2 0}(95.4 \%)$ \\
\hline Nombung TP1 Sakao I. $20-40 \mathrm{~cm}$ & Wk-18953 & $201 \pm 41$ & -23.7 & Charcoal & $\mathbf{3 1 0 - 5 0}(85.4 \%), 40-0(10.0 \%)$ \\
\hline Nombung TP1 $60-80 \mathrm{~cm}$ & Wk-18954 & $206 \pm 33$ & -21.7 & Charcoal & 300-130 (76.5\%), 120-60 (11.5\%), 30-0 (7.4\%) \\
\hline
\end{tabular}

Calibrations using OxCal v. 3.10 (Bronk Ramsey 2005) were provided by Fiona Petchey, University of Waikato, Radiocarbon Dating Laboratory. Calibrations utilize Southern Hemisphere atmospheric data from McCormac et al. (2004). 
Vanuatu (Malo, Makue, Vao, Teouma) indicates that there will indeed be Lapita sites discovered there through further prospection. Again, dramatic geomorphological change has made their discovery difficult. There is certainly no apparent geophysical impediment to the Banks and Torres Islands having been any less attractive for Lapita settlement than any other in Vanuatu.

The evidence for Lapita-period inter-archipelagic interaction in western Remote Oceania that is now emanating from Vanuatu has been increased greatly over the last few years of research. It is providing insights into wider issues such as the pattern and strategy of Lapita settlement in Remote Oceania. There are several trademark artifacts (primarily pottery and obsidian) along with distinctive aspects to midden composition that are seen as proxies in Remote Oceania for identifying colonization-phase settlements and measuring the strength of connections with sites farther to the west, including the Bismarcks homeland (Green 1976, 2003: 114; Green and Kirch 1997; Sheppard 1993).

Prior to recent research in Vanuatu the Reefs-Santa Cruz Group was seen as unique in Remote Oceania for the quantities of Bismarck Archipelago obsidian that had been recovered. But a similar pattern is beginning to emerge from the Lapita sites in Vanuatu, particularly from Makue (Galipaud and Swete-Kelly 2005) and to a lesser extent Teouma. A significant quantity of fine-grained chert, which may be exotic, has also been recovered from Teouma.

Preliminary analysis of the Teouma Lapita ceramics places them in the category of Western or Middle Lapita style (Anson 1983; Summerhayes 2000). There is a wide range of vessel forms present including fine dentate-stamped flat-bottomed dishes, cylinder stands, pot stands, carinated vessels, and incurving bowls. These vessel forms and many of the design motifs show direct parallels with material from the Reefs-Santa Cruz Group Lapita sites and even with sites much further west such as in the Arawe Islands and Mussau Group of the Bismarck Archipelago. To have the range of very similar vessel forms and designs distributed over such great distances implies rapid movement of people out of the Bismarck homeland region into western Remote Oceania (Bedford et al. 2006). Significantly, a number of the same distinctive or parallel attributes found to the northwest of Vanuatu are not found farther east in Fiji and are restricted in their distribution in New Caledonia. Further evidence of the fluid nature of initial Lapita settlement in this region is the identification of a flat-bottomed dish from Teouma that has been sourced to New Caledonia (Dickinson 2006a).

It has long been argued that the Reefs-Santa Cruz Group formed a crucial central place for the colonization of Remote Oceania (Green 1976; Green and Kirch 1997). Their long-distance exchange system and links to the Bismarcks were seen as somewhat unique. This status has been emphasized more recently by Sheppard and Walter (2006:59) although they concede that results from northern Vanuatu suggest that this "zone" may have to be extended farther east. The latest results from northern and central Vanuatu confirm this extension. Rather than the Reefs-Santa Cruz Group being seen as unique, it can now be seen rather as a nodal point and not a terminus in a wider chronozone stretching down to northern and central Vanuatu. The idea that Lapita colonizers may have leap-frogged Vanuatu or that Lapita settlement was marginal in Vanuatu now finds little support; rather the increasing evidence points to the archipelago as being integral to the successful human colonization of western Remote Oceania 
(Bedford in press) and by implication regions farther east. Vanuatu was almost certainly the departure point for the Lapita settlement of Fiji, an argument first put forward long ago (Anson 1983, 1986; Green 1978), and provided an intervisible series of stepping-stone islands southward to New Caledonia.

\section{Post-Lapita Interaction with the Northwest}

The core of archaeological arguments regarding interaction or migratory events post-dating Lapita in the southwest Pacific has revolved around ceramics and as such they will be the focus of discussion here. For decades archaeologists talked of a largely assumed Incised and Applied Relief (IAR) tradition which could be identified across the southwest Pacific which was said to represent a secondary wave of migration following Lapita. This was seen as going part way to explaining the striking cultural, linguistic, and biological differences found between the Melanesian and Polynesian regions. A crucial rupture in this overarching theme came with the recognition that the ceramic sequences of Efate (once seen as a central region of IAR) and Erromango, located an intervisible distance to the south, exhibited divergence soon after the end of dentate-stamped Lapita (Bedford $2000,2006 a$ ). The current project has provided further opportunity to assess the post-Lapita ceramic traditions of Vanuatu and how similar those in the north are to central and southern Vanuatu and regions beyond.

Erueti- and Mangaasi-style pottery have thus far been identified as being widespread on Efate and its outer islands and farther north to the Shepherds Group (Bedford 2006a; Garanger 1972). Recent research undertaken on Epi indicates that this island may, in fact, mark their most northern extent albeit in a diluted form. At the village of Mafilau on the west coast of the island a large mound feature comprised primarily of midden remains has revealed a stratified cultural deposit in excess of $4.5 \mathrm{~m}$ in depth which chronologically parallels the Early Erueti Phase on Efate (2800-2500 B.P.). The pottery is predominantly plain (less than 20 incised sherds amongst thousands of plain sherds) and only partially reminiscent of Early Erueti-style material as it lacks the distinctive wide flat lip.

There are, however, hints that there was some connection: several examples of a distinctive shell artifact that has not been found thus far anywhere else but from Erueti deposits on Efate were found at Mafilau. It is a long unit with perforations at each end (Bedford 2006a:209, Fig. 9.14a), possibly part of a necklace or bracelet. A suite of five radiocarbon dates from the top $4 \mathrm{~m}$ of the mound cluster around 2740-2450 cal. B.P. (see Table 1). A number of surface collected sherds that had been washed down from a nearby gully can be securely grouped with Early Mangaasi-style ceramics (c. 2300-1800 cal. B.P. on Efate). Epi appears to have been a border region during this period. It seems that this border or boundary status, which has shifted its orientation over time, continued well into the late prehistoric period: surface ceramics from Mafilau and farther northwest on Epi dating to the last 500 years have clear parallels with ceramics from Malakula but similar ceramics are not found farther south.

The Malakula ceramic sequence lacks anything that resembles Erueti or Mangaasi in terms of vessel form or full-design motifs. Pottery production continued there right up to European contact some 1200 years after it probably ceases on 
Efate. There are incised, applied, fingernail, and excised decorative techniques that are used on a variety of vessel forms but neither the full designs, the chronology, or the vessel forms are comparable with those in central Vanuatu. From our own recent investigations on Santo and the earlier surveys of Galipaud we again conclude that Erueti- and Mangaasi-style ceramics do not reach that far north.

This conclusion requires reassessment of earlier arguments regarding the Banks Islands ceramics that were once thought to be Mangaasi-like (Kirch and Yen 1982; Ward 1979) and then, later, Erueti-like (Bedford 2000, 2006a) and which disappeared supposedly around 2000 B.P. The recovered Pakea material was in effect too fragmentary to establish anything beyond decorative technique, and hints at some vessel form (as has also been argued for the majority of sites claiming to be associated with IAR [Bedford 2006a; Bedford and Clark 2001]).

Ward recorded numerous sites with surface finds of pottery throughout the Banks and this has been further confirmed on a recent visit by Bedford and Christian Reepmeyer, a Ph.D. student from the Australian National University studying Banks Islands volcanic glass. If pottery had ceased some 2000 years ago then its regular occurrence on the ground surface seems very much at odds with ongoing volcanic activity across much of the Banks. Two radiocarbon dates associated with pottery at the Ambek site on Vanua Lava now confirm that ceramic production continued there into the last 600 years (Table 1). During a brief surface survey in 2006 on Pakea Island off the coast of Vanua Lava a number of large decorated sherds were collected that were unlike anything found there earlier, or found in the sequences of central Vanuatu. Many of the recently recovered sherds also displayed a distinctive red slip both internally and externally, a feature of the late Santo ceramics. While yet to be further clarified we suggest that the ceramic sequence of the Banks is also likely to be characterized by regional diversification soon after Lapita with some late connections to Santo.

Our conclusion, albeit preliminary as none of the ceramic sequences from the north are as robust as those established for the center and south, is that there is regional diversification in ceramic traditions right across Vanuatu soon after Lapita and that these traditions can be divided into a number of regions: southern, central, northern, and far northern Vanuatu (Banks and Torres Islands). This conclusion alone severely weakens support for any overarching IAR, which was once thought to have stretched right across the southwest Pacific and to have represented a similar phenomenon to the Lapita dispersal event. Initial comparisons with sequences to the northwest, the most detailed and secure of which are found in the western Solomons (Felgate 2003) and on Buka (Specht 1969; Wickler 2001), find little support for synchronicity or parallels until we get to the very end of the sequence.

It is the modern forms recorded by Specht (1972:130) from Buka, the coilmade bullet-shaped pots with incised motifs that show marked similarities in manufacturing technique, form, and motif design to late prehistoric and historic ceramics on northern Vanuatu islands such as Malakula, Ambae, Pentecost, Maewo, Malo, and southern Santo (Bedford 2006a; Galipaud 1996a). The evidence for increased interaction with at least the immediate north is also seen in the presence of Banks Islands volcanic glass on Tikopia during the last 1000 years (Kirch and Yen 1982). 


\section{Contact with Fiji}

We do not dispute the fact that there is a range of evidence from various disciplines that indicates there has been contact between Vanuatu and Fiji during the prehistoric period following initial colonization. What we do challenge, however, are the arguments or implications that suggest a major migratory event emanating from Vanuatu occurred around 1700 B.P. and that this event can be identified in the Fijian ceramic record (Best 1984:493, 2002:30-32; Burley and Clark $2003: 239)$. This event or series of events is argued to have been a major influence in the transformation of the Fijian ceramic tradition at that time, heralding the development of the Navatu Phase across Fiji.

Best, who has been the strongest recent advocate of a migratory event from Vanuatu, conceded that following reassessments of the central and southern Vanuatu ceramic sequences (Bedford 2006a; Bedford and Clark 2001), parallels with that region and Fiji now seemed unlikely. He does persist, however, with the idea that ceramic parallels with Navatu Phase ceramics might still be found in the north of Vanuatu (Best 2002:30-32).

Burley is apparently less confident as regards a migratory event, although he is generally supportive of Best's arguments. He champions the idea of an "intrusion of ceramic influences from the west," but suggests instead that this came about through the "result of occasional contacts through interisland voyaging" (Burley 2005:339). Unlike Best, Burley continues to see parallels with Mangaasi-style pottery, but in his summary of both Navatu and Fijian Plainware phase vessels only a single example is cited $(2005: 330)$ in a collection which is overwhelmingly and distinctively Fijian in terms of vessel form, decorative technique, and design motifs. On current evidence we remain unconvinced of a migratory event from Vanuatu that transformed a long-established Fijian ceramic tradition. Indeed the accumulating data from Vanuatu that the ceramic sequences there demonstrate regional diversification would appear to further weaken this claim.

The Banks Islands basaltic glass (14 pieces) found in two rockshelters on the island of Lakeba (Best 1984:65) provides strong evidence of an exotic article derived from northern Vanuatu being present in eastern Fiji. However, and particularly considering that to date this has been a one-off find, to us it hardly constitutes evidence for a major migratory event. We suggest rather that this is the sort of data that points to evidence of occasional low-level contacts (Burley 2005:339; Clark 2003:215). The dating of the basaltic glass, fitting in with changes in ceramics at the site at 1700 B.P., has also been challenged (Bedford and Clark 2001:69). If an equally feasible date of 1200 B.P. is accepted then it coincides with a period of broader expansion of the distribution of Banks Islands glass (and a range of other artifact forms), north to Tikopia (Kirch and Yen $1982: 260)$. It is also a period which marks increased interaction among the islands of northern Vanuatu in general, a characteristic which continued into the historic period, facilitated by the use of large ocean going canoes that were recorded ethnographically (Fig. 2).

There are also intriguing parallels with aspects of northern Vanuatu ceremonial activity that have been noted in the late ceremonial sites known as Naga in Fiji. These sites have yet to be investigated in any detail but they are recognized as 

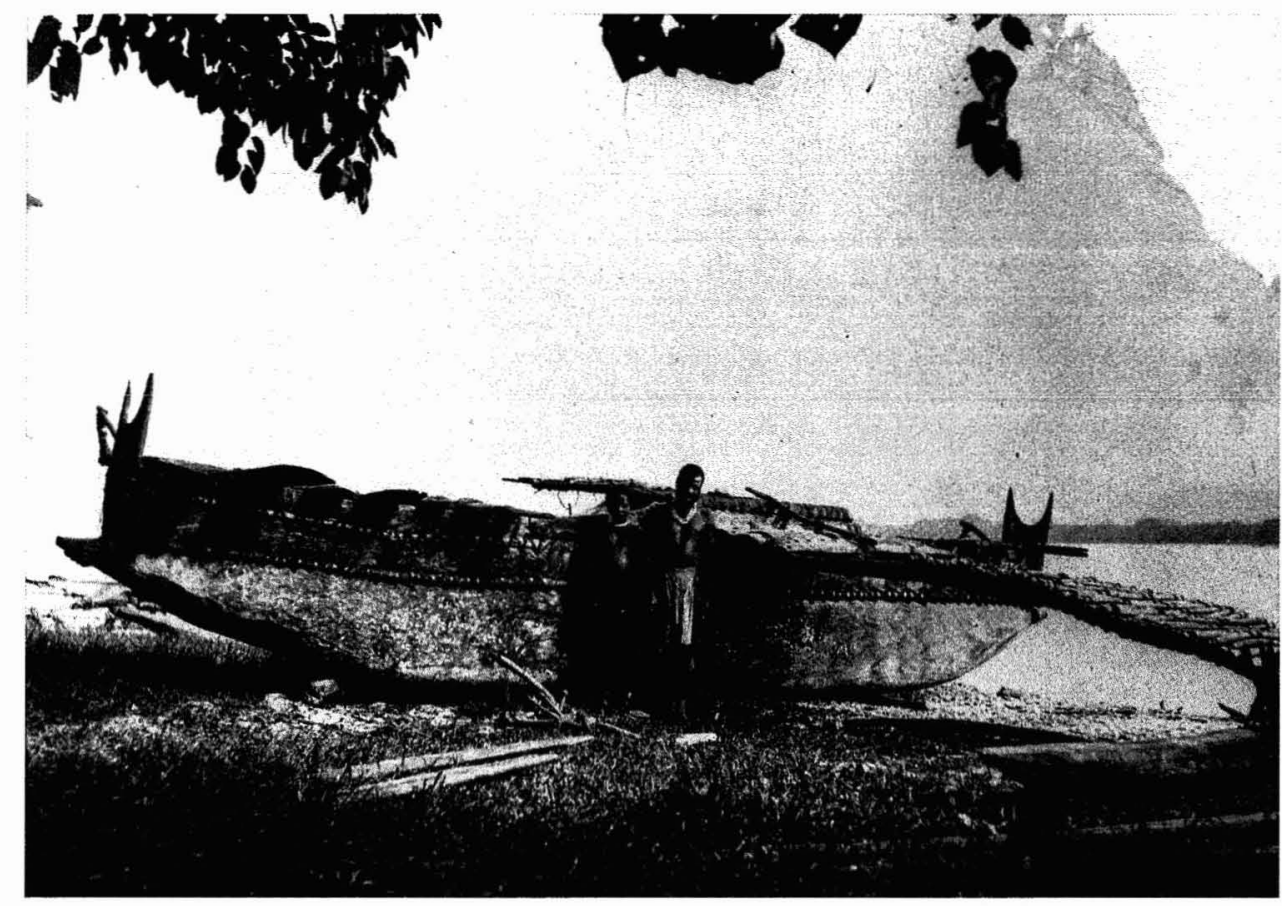

Fig. 2. Oceangoing canoe, SE Santo, c. 1885. Photograph courtesy of the Vanuatu National Museum.

being relatively late and the stone structures are unlike any others found in Fiji (Field 2006; Fison 1885; Frost 1979; Palmer 1971). The pottery associated with these sites, elongated forms with pointed bases, finds few parallels among any other Fijian material. The sites were associated with "secret society" activity including male initiation ceremonies. At the beginning of these ceremonies initiates had their heads shaved, which according to one record "presented a curious appearance ... owing to the remarkable shape of their heads, which are narrowed by lateral pressure during infancy" (Fison 1885:20). As noted earlier, similar cranial deformation was a feature of northern Vanuatu and some Bismarck Archipelago societies at European contact.

\section{The Extent of Polynesian Contacts with Northern Vanuatu}

Evidence for Polynesian influence in Vanuatu has been commented on since the arrival of Cook and has been highlighted through a range of evidence including oral traditions, ethnographic observations, linguistics, and archaeology. The primary archaeological evidence for this contact comes from a range of artifact forms dated to the last 1000 years, thus far restricted to the center and south of Vanuatu, and principally derived from burials (Bedford 2006a:216; Garanger 1972; Shutler and Shutler 1968; Shutler et al. 2002; Spriggs 1997a:207-218).

The more recent fieldwork undertaken in northern Vanuatu on sites dating to a similar period, including excavated burials on both Malakula and Epi, has so far 
failed to produce anything comparable to the range of Polynesian-style artifacts found in the center and south of Vanuatu. We conclude, on admittedly much less detailed archaeological data than that available for the center and south, that Polynesian influence in northern Vanuatu was indeed rare and unimportant. However, this opens up the question of the different levels and situations of contact or interaction and how they might be manifested in the archaeological record.

The burials most often associated with Polynesian-style artifacts, the presence of which is generally attributed to West Polynesian expansion, are those of Roi Mata on Retoka, others on Tongoa, and then Aneityum in the south. But at the same time there are distinctive features of these burials that would seem to have derived from northern Vanuatu. These include the occurrence of full-circle pig tusks, a signature artifact of the graded society in northern Vanuatu and, in the case of the burials on Aneityum, the practice of removal of the head after decomposition. The nature of Polynesian contact clearly varied from place to place and the evidence thus far indicates that it was more sustained in the south and centre of Vanuatu. Neither conquest nor major migratory events need be invoked necessarily to explain conscious or unconscious processes of imitation, adaptation, or inclusion of exotic cultural practices and material culture. The appearance of Polynesian-style artifacts in the center and south of Vanuatu coincides with evidence for a more general increase in archipelagic interaction across the Western Pacific (Bedford and Clark 2001:71; Kirch 2000:129; Spriggs 1997a:187-222). This wider phenomenon was not solely Polynesian-driven or inspired.

One of the factors which further complicates an assessment of the levels of external impact in any region and particularly those of a sociopolitical nature, is the potential for subsequent influences from elsewhere having masked or replaced them. Might this have been the scenario in Vanuatu in relation to the contrasting political systems found in the north (grade-taking system) and the center and south (Polynesian-style chiefly systems)? We think generally not, even if simply based on an assessment of the currently available information on material culture and burials of similar chronological periods rather than any detailed history of the grade-taking system.

Our research and that of others highlight the varied development, form, fluid nature, and in some cases very recent appearance of the grade-taking systems found across northern Vanuatu. On some islands oral traditions claim that the grade-taking systems developed on those islands and have always been there, while on others people say they were introduced from elsewhere in the recent past. Similarly in relation to pig killing being an integral part of the grade-taking system, people on some islands talk of pigs as always being an essential component while others talk of "pig missionaries" arriving in areas just before the church missionaries in the nineteenth century (Huffman 2005, and pers. comm.). In southeast Ambrym a further ingredient to the mix included a diluted form of chieftainship that operated in tandem with the graded society (Tonkinson 1968:27-28).

\section{Emergence of the Ethnographic Present}

Increased European activity and more sustained contact began in Vanuatu soon after the visit of Cook in 1774 and particularly so after Peter Dillon's announce- 
ment in 1825 that sandalwood was present on the southern islands. Missionary activity from the 1840 s and labor recruitment from the 1860 s radically increased the intensity and impact on ni-Vanuatu society at all levels. It was a period of immense change, most dramatically demonstrated in the records of massive depopulation (Spriggs 1997a:255-263), of adaptation, and transformation. Historical records for this period are varied both in terms of their focus, coverage and detail. Prior to the 1840s they are few and far between and increase in number from the mid-nineteenth century, primarily as a result of missionary activity.

Early detailed ethnographic studies and anthropological research date from the late nineteenth and early twentieth centuries (Codrington 1891; Deacon 1934; Layard 1942; Speiser 1923, 1996) and were understandably patchy in their coverage. Bearing this in mind one has to approach the written and oral historical record with a degree of caution, particularly if assigning any time depth to observed social, economic, and cultural behavior. Initial contacts and subsequent interaction between ni-Vanuatu and the new arrivals varied tremendously across the archipelago and consequently the levels of impact, change, and adaptation were equally variable and often unpredictable.

There are numerous cases of underlying indigenous social and political institutions being enhanced through increased contacts, particularly with European traders. Grade-taking ceremonies on the west coast of Ambae are said to have reached their zenith in terms of largesse and display in the mid-1860s, at least partly stimulated by increased access to tusker pigs through amplified trade (Allen 1969). This may well have been the case in many of the grade-taking areas of Vanuatu and it is of course the same period when they begin to be described and recorded in detail. Those items of introduced material culture most prized were generally those that filled the same role of traditional items. In the $1860 \mathrm{~s}$, the most prized trade items in Vanua Lava in the Banks Islands, where volcanic glass was still being used, were empty whole bottles (Brenchley 1873 :235). Iron cooking vessels too appear to have been readily adopted, even in areas where pottery was still being made or exchanged.

Virtually all historic records that mention pottery indicate that its manufacture was restricted to the west coast of Santo and that it was traded to other areas from there. There is, however, regular mention of the widespread presence of potsherds across central and northern Vanuatu. Pottery is very rarely noted as being used outside Santo, accounts being restricted to Malakula where pieces of pots were used in various ceremonies. Recent archaeological and linguistic research indicates, however, that this pattern probably developed very recently in parts of northern Vanuatu: it cannot be extended back beyond the early to midnineteenth century.

Excavations of well-stratified (due to regular ashfall from nearby Ambrym) late midden deposits at Nombung on Sakao Island, one of the Maskelyne Islands off the southeastern tip of Malakula, have revealed the transition between late precontact and post-contact midden remains. In a one-meter-deep deposit pottery dominates in the lower immediately pre-European contact levels, is mixed with limited exotic materials (iron and glass) in layers above dated to less than $310 \mathrm{cal}$. B.P., and is no longer present in the uppermost levels dominated by historically introduced items (see Table 1 for dates). Much of the island was sold to European interests in 1884. Linguistically similar terms for cooking pots also give some 
indication of areas where its manufacture or use has only been relatively recently lost. On Sakao the language term for cooking pot is koro, as it is in southwest Malakula, and it is vuru on south Ambae. On the west coast of Santo it is uro. In many areas where pottery had long ago gone out of use, it is simply referred to by the Bislama (pidgin) term "sospen" from English "saucepan."

The sudden and historically unrecorded disappearance of pottery in northern Vanuatu highlights the kind of major change than can occur in a short period of time: in this case it is likely to have occurred in less than a generation. Ethnographic records must also be weighed against radically changing natural landscapes in a volcanically active archipelago such as Vanuatu. What might be assumed to be a long-lived landscape and human settlement pattern may in fact be only a relatively recently established situation (Bedford and Spriggs in prep.). Many of the features pertaining to the exchange networks recorded in northern Vanuatu (Fig. 1) in the mid- to late nineteenth and early twentieth centuries may in fact be related to responses to changing circumstances brought about by European intrusion. However these high impact events or processes that happen over a relatively short period are often very difficult to identify in the archaeological record in deflated and often very mixed contexts, particularly if sampling is not carried out intensively across the wider landscape. This we found was the case with our so-far failed attempts to identify impacts associated with the 1606 Spanish visit to Big Bay in Santo. Evidence for such impacts is at present "lost" in a sea of unfamiliar and as yet undescribed data with no clear chronological context (cf. Walter and Sheppard 2006).

\section{SUMMARY AND CONCLUSIONS}

The increased pace of archaeological research in Vanuatu over the last decade has transformed our knowledge and perceptions of the archipelago's deep history. It has also provided a vastly more robust data set from which the archipelago can be assessed and situated in the wider Pacific context. The primary colonization of Vanuatu can be shown to have been associated with the initial human settlement of Remote Oceania. A chronozone once thought to be restricted to the ReefsSanta Cruz Group can now be extended farther south to northern and central Vanuatu. Internally, Lapita sites have now been found on some of the smaller islands of Vanuatu (some less than $1 \mathrm{~km}^{2}$ ) through to the largest island of Santo. Any previously perceived preference for small offshore islands can now be seen, at least in the case of Remote Oceania, as simply a factor of site visibility and ease of investigation.

The emerging data indicate that there are early nodal settlements and a whole series of satellite and later settlements, some of which are occupied for hundreds of years while others are very short-term. Population movements are very fluid during this initial colonization phase, evidenced through the presence of exotic Lapita pots from New Caledonia in the south, center, and north of Vanuatu (Dickinson 2006a, 2006b) and Banks Islands obsidian reaching as far south as Efate (Ambrose pers. comm.).

We can also now say with increasing confidence that soon after the Lapita dentate-stamped phase of ceramic production, there is regional diversification in ceramic traditions across Vanuatu. These multiple traditions do not demonstrate synchronous change or any great level of similarity with chronologically compa- 
rable ceramic sequences elsewhere. Consequently they do not provide evidence of waves of secondary migration or high levels of sustained interaction. A crucial aspect of this whole debate that is often overlooked is the need for an assessment of the integrity and nature of any of the ceramic collections that are being studied. Comparisons are often made with collections of small sherds from which nothing more than decorative technique can be assessed. If robust local ceramic sequences are to be established, which can then be reliably used in regional comparisons, then it is crucial that they be based on collections that enable the reliable reconstruction of vessel forms and give some indication and definition of complete decorative designs.

Not having evidence for homologous ceramic sequences in neighboring archipelagoes need not of course in any way preclude interaction. There needs to be greater emphasis on the cultural processes involved and how these might be manifested in the archaeological record (cf. Green and Kirch 1997). While Lapita represents a major migratory event and is associated with an identifiable ceramic horizon, "Melanesianization," for want of a better word, can be much more productively "construed as an interactive process rather than a dispersal event" (Clark $2003: 215)$. Such processes are likely to have continued over millennia and will require long-term, fine-grained regional studies to be further understood.

Vanuatu is an archipelago that was once thought to have an all embracing and well-defined Incised and Applied Relief (IAR) tradition. Through further research it can now be demonstrated to comprise a series of unrelated regional sequences that still require further refinement. This may also be the case in other parts of the Pacific. Although a broad outline of the Fijian ceramic sequence was established decades ago there remains some dispute among archaeologists working in Fiji in regards to how definitive that sequence is (Anderson et al. 2006; Burley $2005: 337-341)$.

The more archaeology that is undertaken in any region, the more complex the picture becomes. There is an increasing awareness that what survives in the archaeological record only tells a small part of the story (Bedford 2006b; Kirch and Green $2001: 164)$. It is only through a multi-disciplinary holistic approach (Kirch and Green 2001; Walter and Sheppard 2006:155) targeting well-defined regions and chronological periods that the historical complexity of the western Pacific will be better understood. If it is accepted as a given that Pacific peoples and cultures were changing and dynamic then the ethnographic record must be assessed in that context. It is in effect an eclectic collection of "snapshots," restricted largely to the last 150 years, that may or may not have any time depth. Recent research shows that there are many challenges for archaeologists working in the Pacific who attempt to develop more sophisticated explanations for the myriad human behaviors that have contributed to the cultural development, transformation, and diversity that is found across the region today.

\section{ACKNOWLEDGMENTS}

This paper reports on a project which commenced in 2005. Thus far two years of the anticipated three-year project have been undertaken and the results and discussion presented here should be considered preliminary and very much a work-inprogress. Investigations across Vanuatu are being undertaken as a joint project of the Australian National University and the Vanuatu National Museum. Primary 
funding for the northern Vanuatu archaeological project has been provided by the Australian Research Council (DP 0556874), along with additional funding for Teouma from the National Geographic Society, Pacific Biological Foundation, the Royal Society of New Zealand (Marsden Faststart), Snowy Mountains Electricity Commission Foundation, the Department of Archaeology and Natural History, and School of Archaeology and Anthropology, Australian National University. We thank particularly all Chiefs, landowners, and communities in the areas we have worked for their permission, collaboration, and enthusiasm. Staff of the Vanuatu Cultural Centre (VCC), particularly the Director Ralph Regenvanu and VCC fieldworkers provided essential support. Fieldwork on various islands was made easier with the participation of Jacques Bolé, Hallie Buckley, Willy Damelip, Stuart Hawkins, Andrew Hoffman, and Frédérique Valentin. Figure 1 is taken from a figure previously published by Kirk Huffman. His permission for use and adaptation of the figure was graciously given. It was drawn by Jennifer Sheehan, Cartographic Services, RSPAS, ANU. Comment and key references were provided by Wal Ambrose, Atholl Anderson, Geoff Clark, Julie Field, Roger Green, Kirk Huffman, and Peter Sheppard, none of whom necessarily subscribe to the views presented here.

\section{NOTE}

1. Following Weisler (1997:13) we use interaction as a general term "to denote some form of intergroup communication." The term contact is used where the nature of such intergroup communication is likely to have been unequal, as in the case of European and Polynesian influences. We are mindful, in this regard, of the strictures of Frederick (1999:133-135) in relation to constructions of contact and its inequalities. More loaded terms such as trade or exchange are avoided in the text unless there is clear evidence of two-way movement of goods or services involved in the situation described.

\section{REFERENCES CITED}

Allen, Michael

1969 Report on Aoba. Incidental papers on Ndui Ndui district, Aoba Island, New Hebrides, ed. C. Leaney. Port Vila: British Residency.

Ambrose, Wallace R.

1976 Obsidian and its distribution in Melanesia, in Ancient Chinese bronzes and South East Asian metal and other archaeological artifacts: 351-378, ed. Noel Barnard. Melbourne: National Gallery of Victoria.

Anderson, Atholl, and Geoff Clark

1999 The age of Lapita settlement in Fiji. Archacology in Oceania 34:31-39.

Anderson, Atholl, Stuart Bedford, Geoff Clark, Ian Lilley, Christophe Sand, Glenn SumMERHAYES, AND ROBIN TORRENCE

2001 An inventory of Lapita sites containing dentate-stamped pottery, in The archaeology of Lapita dispersal in Oceania: Papers from the Fourth Lapita Conference, June 2000, Canberra, Australia: 1-14, ed. G. Clark, A. Anderson and T. Sorovi-Vunidilo. Terra Australis 17. Canberra: Centre for Archaeological Research and Department of Archaeology and Natural History, Australian National University.

Anderson, Atholl, Richard Roberts, William Dickinson, Geoff Clark, David Burley, Antoine de Biran, Geoff Hope, and Patrick Nunn

2006 Times of sand: Sedimentary history and archaeology at the Sigatoka Dunes, Fiji. Geoarchaeology $21(2): 131-154$.

Anson, Dimitri

1983 Lapita pottery of the Bismarck Archipelago and its affinities. Unpublished Ph.D. diss. University of Sydney.

1986 Lapita pottery of the Bismarck Archipelago and its affinities. Archaeology in Oceania 21(3): 157-165. 
BEDFORD, STUART

2000 Pieces of the Vanuatu puzzle: Archaeology of the North, South and Centre. 2 vols. Ph.D. diss. Australian National University, Canberra.

2003 The timing and nature of Lapita colonisation in Vanuatu: The haze begins to clear, in $\mathrm{Pa}$ cific archaeology: Assessments and prospects (Proceedings of the Conference for the 50th anniversary) of the first Lapita excavation, Kone-Nouméa 2002): 147-158, ed. Christophe Sand. Nouméa: Les Cahiers de l'archéologie en Nouvelle-Calédonie 15.

2006 a Pieces of the Vanuatu puzzle: Archaeology of the North, South and Centre. Terra Australis 23. Canberra: Pandanus Press, Australian National University.

$2006 \mathrm{~b}$ The Pacific's earliest painted pottery: an added layer of intrigue to the Lapita debate and beyond. Antiquity 80:544-557.

in press Crucial first steps into Remote Oceania: Lapita in the Vanuatu archipelago, in From Southeast Asia to the Pacific. Archaeological perspectives on the Austronesian expansion and the Lapita cultural complex, ed. S. Chiu and C. Sand. Taipei: Academia Sinica.

Bedford, Stuart, and Geoffrey Clark

2001 The Rise of the Incised and Applied Relief Tradition: A review and reassessment, in The archaeology of Lapita dispersal in Oceania: Papers from the Fourth Lapita Conference, June 2000, Canberra, Australia: 61-74, ed. G. Clark, A. Anderson, and T. Sorovi-Vunidilo. Terra Australis 17. Canberra: Centre for Archaeological Research and Department of Archaeology and Natural History, Australian National University.

Bedford, Stuart, and Matthew Spriggs

2000 Crossing the Pwanmwou: Preliminary Report on recent excavations adjacent to and southwest of Mangaasi, Efate Vanuatu. Archaeology in Oceania 35:120-126.

in prep. A rediscovered archaeological landscape affected by catastrophic volcanism on Ambae Island, Vanuatu.

Bedford, Stuart, Matthew Spriggs, and Ralph Regenvanu

2006 The Teouma Lapita site and the early human settlement of the Pacific Islands. Antiquity $80: 812-828$.

Bedford, Stuart, Andrew Hoffman, Martha Kaltal, Ralph Regenvanu, and Richard Shing 2004 Dentate-stamped Lapita reappears on Efate, central Vanuatu: A four decade-long drought is broken. Archaeology in New Zealand 47(1):39-49.

Best, Simon

1984 Lakeba: The prehistory of a Fijian Island. Ph.D. diss. Department of Anthropology, University of Auckland.

1987 Long-distance obsidian travel and possible implications for the settlement of Fiji. Archaeology in Oceania 22:31-32.

2002 Lapita: A view from the East. Auckland: New Zealand Archaeological Association Monograph 24.

BonNemaison, Jö̈L

1996 Graded societies and societies based on title: Forms and rites of traditional political power in Vanuatu, in Arts of Vanuatu: 200-203, ed. J. Bonnemaison, K. Huffman, C. Kaufmann, and D. Tryon. Bathurst: Crawford House Press.

Bonnemaison, Joël, Kirk Huffman, Christian Kaufmann, and Darrel Tryon, eds.

1996 Arts of Vanuatu. Bathurst: Crawford House Press.

BrenCHLEY, JohN L.

1873 Jottings during the cruise of H.M.S. Curaçoa among the South Sea Islands in 1865. London: Longmans, Green.

Bronk Ramsey, Christopher

2005 OxCal program v. 3.10. Oxford: University of Oxford Radiocarbon Unit. http:// www.rlaha.ox.ac.uk/oxcal/oxcal.htm

Burley, David

2005 Mid-sequence archaeology at the Sigatoka sand dunes with interpretive implications for Fijian and Oceanic culture history. Asian Perspectives 44(2):320-348.

Burley, David, and JefFrey Clark

2003 The archaeology of Fiji/Western Polynesia in the post-Lapita era, in Pacific Archaeology: Assessments and prospects (Proceedings of the Conference for the 50th anniversary of the first Lapita excavation, Kone-Nouméa 2002): 235-254, ed. Christophe Sand. Nouméa: Les Cahiers de l'archéologie en Nouvelle-Calédonie 15. 
Burley, David, and William Dickinson

2001 Origin and significance of a founding settlement in Polynesia. Proceedings of the National Academy of Sciences 98(20): 11829-11831.

Burley, David, Earle Nelson, and Richard Shutler Jr

1999 A radiocarbon chronology for the eastern Lapita frontier in Tonga. Archaeology in Oceania $34: 59-70$.

Clark, Geoffrey

2003 Dumont d'Urville's Oceania. Journal of Pacific History 38(2) : 155-161.

Clark, Geoffrey, and Atholl Anderson

2001 The pattern of Lapita settlement in Fiji. Archaeology in Oceania 36(2):77-88.

Codrington, Robert H.

1891 The Melanesians: Studies in their anthropology and folk-lore. Oxford: Oxford University Press.

DeACON, Bernard

1934 Malekula: A vanishing people in the New Hebrides. London: Routledge and Sons.

Dickinson, William

2001 Petrography and geologic provenance of Sand Tempers in Prehistoric potsherds from Fiji and Vanuatu, South Pacific. Geoarchaeology 16(3):275-322.

$2006 a$ Petrography of Sand Tempers in prehistoric potsherds from selected islands in central and northern Vanuatu, New Hebrides Island Arc. Unpublished Petrographic Report WRD255.

$2006 b$ Temper Sands in prehistoric Oceanian pottery: Geotectonics, sedimentology, petrography, provenance. Geological Society of America Special Paper 406. Boulder, CO: Geological Society of America.

EARLe, Timothy, ED.

1991 Chiefdoms: Power, economy, and ideology. Cambridge: Cambridge University Press.

1997 How chiefs come to power: The political economy in prehistory. Stanford, CA: Stanford University Press.

Felgate, Matthew

2003 Reading Lapita in Near Oceania: Intertidal and shallow-water pottery scatters, Roviana Lagoon, New Georgia, Solomon Islands. Unpublished Ph.D. diss. University of Auckland.

FiELD, JULiE

2006 The prehistory of the interior of Vitilevu. Domodomo 19:7-19.

FISON, LORIMER

1885 The Nanga, or sacred stone enclosure of Wainimala, Fiji. The Journal of the Anthropological Institute of Great Britain and Ireland 14:14-31.

Frederick, URSUla K.

1999 At the centre of it all: Constructing contact through the rock art of Watarrka National Park, central Australia. Archaeology in Oceania 34(3):132-143.

Frost, Everett L.

1979 Fiji, in The prehistory of Polynesia: 61-81, ed. J. D. Jennings. Cambridge, MA: Harvard University Press.

Galipaud, Jean-Christophe

$1996 a$ Le rouge et le noir: La poterie Mangaasi et le peuplement des îles de Melanésie, in Mémoires de Pierre, Mémoires d'Homme: Tradition et archéologie en Océanie. Hommage à José Garanger: 115-125, ed. M. Julien, M. Orliac, B. Gérard, A. Lavondès, H. Lavondès, and C. Robineau. Paris: Publications de la Sorbonne.

1996 Premiers resultants de la mission archéologique Wusi-Hokua. Rapport de Terrain. Port Vila: ORSTOM.

1998a The Lapita site of Atanoasao Malo, Vanuatu. Field Report No. 8. Port Vila: ORSTOM (also published in 2000 in World Archaeological Bulletin 12:41-55).

1998 Recherches archéologiques aux îles Torres. Journal de la Société des Océanistes 107(2):159168.

2001 Survey of prehistoric sites in Aore. Preliminary assessment. Unpublished report to Vanuatu Cultural Centre. 
Galipaud, Jean-Christophe, and Mary Clare Swete-Kelly

2005 New evidence relating to the transport of Talasea obsidian to Vanuatu. Paper presented at Oceanic Explorations Conference, August, Tonga.

Galipaud, Jean Christophe, and Bernard Vienne

2005 Chronologie du peuplement et réseaux d'échanges dans le nord du Vanuatu. Mission Santo 2005. Rapport préliminaire. Nouméa: IRD.

GARANGER, José

1972 Archéologie des Nouvelles-Hébrides: Contribution à la connaissance des îles du centre. Publications de la Société des Océanistes, No. 30. Paris: ORSTOM.

Geraght y, Paul

1983 The history of Fijian languages. Oceanic Linguistics Special Publication No. 19. Honolulu: University of Hawai'i Press.

Goldman, IrVing

1970 Ancient Polynesian society. Chicago: University of Chicago Press.

GOLSON, JACK

1961 Report on New Zealand, Western Polynesia, New Caledonia and Fiji. Asian Perspectives 5(2): $166-180$

Green, Roger C.

1963 A suggested revision of the Fiji sequence. Journal of the Polynesian Society 72:235-253.

1976 Lapita sites in the Santa Cruz Group, in Southeast Solomon Islands cultural history. A preliminary survey: 245-265, ed. R. C. Green and M. M. Cresswell. The Royal Society of New Zealand, Bulletin 11. Wellington.

1978 New sites with Lapita pottery and their implications for an understanding of the settlement of the Western Pacific. Working Papers in Anthropology, Archaeology and Maori Studies, No. 51. Auckland: Department of Anthropology, University of Auckland.

1991 Near and Remote Oceania: Disestablishing 'Melanesia' in culture history, in Man and a half: Essays in Pacific anthropology and ethnobiology in honour of Ralph Bulmer: 491-502, ed. A. Pawley. Polynesian Society Memoir 48. Auckland: The Polynesian Society.

1999 Evidence suggesting inputs of non-Austronesian culture and genes into Vanuatu in the last 1000 years. Paper presented at the New Zealand Archaeological Association Conference, Auckland.

2000 Lapita and the cultural model for intrusion, integration and innovation, in Australian archaeologist: Collected papers in honour of Jim Allen: 372-392, ed. A. Anderson and T. Murray. Canberra: Coombs Academic Publishing.

2003 The Lapita horizon and traditions - Signature for one set of oceanic migrations, in Pacific archaeology: Assessments and prospects (Proceedings of the Conference for the 50th anniversary of the first Lapita excavation, Kone-Nouméa 2002): 95-120, ed. Christophe Sand. Nouméa: Les Cahiers de l'archéologie en Nouvelle-Calédonie 15.

Green, Roger C., and Patrick V. Kirch

1997 Lapita exchange systems and their Polynesian transformations: Seeking explanatory models, in Prehistoric long-distance interaction in Oceania: An interdisciplinary approach: 19-37, ed. M. Weisler. NZAA Monograph 21. Auckland: New Zealand Archaeological Association.

HEDRICK, JOHN

n.d. Archaeological investigations of Malo prehistory. Lapita settlement strategy in the Northern New Hebrides. Manuscript draft of Ph.D. diss. University of Pennsylvania.

Hedrick, John, and Mary E. Shutler

1969 Report on "Lapita style" pottery from Malo Island, Northern New Hebrides. Journal of the Polynesian Society 78(2): 262-265.

HuFFMAN, KirK

1996 Trading, cultural exchange and copyright: Important aspects of Vanuatu arts, in Arts of Vanuatu: 182-194, ed. J. Bonnemaison, K. Huffman, C. Kaufmann, and D. Tryon. Bathurst: Crawford House Press.

2005 Traditional money banks in Vanuatu: Project survey report. Port Vila: Vanuatu National Cultural Council.

IRWIN, GEOFFREY

1992 The Prehistoric exploration and colonisation of the Pacific. Cambridge: Cambridge University Press. 


\section{Kelly, Celsus}

1966 La Austrialia del Espiritu Santo. The journal of Fray Martin de Munilla O.F.M. and other documents relating to the voyage of Pedro Fernandez de Quiros to the South Sea (1605-1606) and the Franciscan Missionary Plan (1617-1627). 2 volumes. London: Hakluyt Society.

Kirch, Patrick V.

1997 The Lapita peoples. Ancestors of the Oceanic world. Oxford: Blackwell.

2000 On the road of the winds. An archaeological history of the Pacific Islands before European contact. Berkeley: University of California Press.

Kirch, Patrick V., and Roger C. Green

2001 Hawaiki, ancestral Polynesia. An essay in historical anthropology. Cambridge: Cambridge University Press.

Kirch, Patrick V., and Douglas E. Yen

1982 Tikopia: The prehistory and ecology of a Polynesian outlier. B.P. Bishop Museum Bulletin 238.

LAYARD, JOHN W.

1942 The stone men of Malakula: The small island of Vao. London: Chatto and Windus.

Leavesley, Matthew, and John Chappell

2004 Buang Merabak: Additional early radiocarbon evidence of the colonisation of the Bismarck Archipelago, Papua New Guinea. Antiquity 78, No. 301. http://www.antiquity .ac.uk/projgall/leavesley/index.html

LUDERS, DAVID

1996 Legend and history: Did the Vanuatu-Tonga kava trade cease in A.D. 1447? Journal of the Polynesian Society 105(3): 287-310.

2001 Retoka revisited and Roimata revised. Journal of the Polynesian Society 110(3):247-287.

McCormac F. Gerry, Alan G. Hogg, Paul G. Blackwell, Caithin E. Buck, Thomas F. G. Higham, and Paul J. Reimer

2004 SHCal04 Southern Hemisphere Calibration 0-1000 cal BP. Radiocarbon 46:1087-1092.

Mondragon, Carlos

2003 Las ples, las aelan, las tingting: Living respect and knowledge in the Torres Islands, Vanuatu. A study of traditional environmental knowledge in Island Melanesia. Ph.D. diss. Cambridge University.

Noury, Arnaud

1998 La poterie Lapita au Vanuatu: étude des décors. Maîtrise de préhistoire océanienne. Université PARIS-1 Panthéon-Sorbonne.

Palmer, Bruce

1971 Naga ceremonial sites in Navosa upper Sigatoka Valley. Final Report No. 1. Records of the Fiji Museum 1(5): 92-106.

Pineda, Rufino, and Jean-Christophe Galipaud

1998 Évidences archéologiques d'une surrection différentielle de l'île de Malo (archipel du Vanuatu) au cours de l'Holocène récent. C.R. Acad. Sci. Paris, Sciences de la terre et des planètes $327: 777-779$.

Sahlins, Marshall

1958 Social stratification in Polynesia. Seattle: American Ethnological Society.

1963 Poor man, rich man, big-man, chief: Political types in Melanesia and Polynesia. Comparative Studies in Society and History 5:285-303.

SAND, Christophe

1995 "Le Temps d'Avant": La préhistoire de la Nouvelle-Calédonie. Paris: L'Harmattan.

1997 The chronology of Lapita ware in New Caledonia. Antiquity 71:539-547.

2000 The specificities of the 'Southern Lapita Province': The New Caledonian case. Archaeology in Oceania 35(1):20-33.

Sheppard, Peter

1993 Lapita lithics: Trade/exchange and technology. A view from the Reefs/Santa Cruz. Archacology in Oceania 28:121-137.

Sheppard, Peter, and Richard Walter

2006 A revised model of Solomon Islands culture history. Journal of the Polynesian Society' $115(1): 47-76$. 
Shutler, Mary E., ANd Richard Shutler JR

1968 A preliminary report of archaeological explorations in the southern New Hebrides. Asian Perspectives (for 1966) 9:157-166.

Shutler, Mary E., Richard Shutler Jr, and Stuart Bedford

2002 Further detail on the archaeological explorations in the Southern New Hebrides, 19631964, in Fifty years in the field: Essays in honour and celebration of Richard Shutler Jr's archaeological career: 189-206, ed. S. Bedford, C. Sand, and D. Burley. NZAA Monograph 25. Auckland: New Zealand Archaeological Association.

Specht, Jim

1969 Prehistoric and modern pottery industries of Buka Island, T.P.N.G. Unpublished Ph.D. diss. Australian National University, Canberra.

1972 The pottery industry of Buka Island, T.P.N.G. Archaeology and Physical Anthropology in Oceania $7(2): 125-144$.

SPEISER, FELIX

1923 Ethnographische materialien aus den Neuen Hebriden und den Banks Inseln. Berlin: C. W. Kreidel.

1996 Ethnology of Vanuatu. An early twentieth century study. Bathurst: Crawford House Press.

Spriggs, MatThew

1981 Vegetable kingdoms: Taro irrigation and Pacific prehistory. Ph.D. diss., Australian National University, Canberra.

1997a The island Melanesians. Oxford: Blackwell.

1997b Landscape catastrophe and landscape enhancement: Are either or both true in the $\mathrm{Pa}-$ cific?, in Historical ecology in the Pacific Islands: Prehistoric environmental and landscape change: 80-104, ed. P. Kirch and T. Hunt. New Haven and London: Yale University Press.

2000 The Solomon Islands as bridge and barrier in the settlement of the Pacific, in Australian archaeologist: Collected papers in honour of Jim Allen: 348-364, ed. A. Anderson and T. Murray. Canberra: Coombs Academic Publishing.

2003 Chronology of the Neolithic transition in Island Southeast Asia and the Western Pacific: A view from 2003. Review of Archaeology 24(2):57-80.

2004 Is there life after Lapita, and do you remember the 60s? The post-Lapita sequences of the Western Pacific, in A Pacific odyssey: Archaeology and anthropology in the Western Pacific. Papers in honour of Jim Specht: 139-144, ed. V. Attenbrow and R. Fullager. Records of the Australian Museum, Supplement 29. Sydney: Australian Museum.

2005 Ethnographic parallels and the denial of history: A critique from Melanesia. David Clarke Memorial Lecture for 2003-2005, University of Cambridge, April.

Summerhayes, Glenn

2000 Lapita interaction. Terra Australis 15. Canberra: Department of Archaeology and Natural History and the Centre for Archaeological Research, Australian National University.

TONKINSON, ROBERT

1968 Maat village, Efate: A relocated community in the New Hebrides. Eugene: Department of Anthropology, University of Oregon.

VISSER, EDWARD

1994 The prehistoric people of Sigatoka: An analysis of skeletal and dental traits as evidence of adaptation. Ph.D. diss. Otago University, Dunedin.

WAHOME, EPHraim W.

1999 Ceramics and prehistoric exchange in the Admiralty Islands, Papua New Guinea. Unpublished Ph.D. diss. Australian National University, Canberra.

Walter, Richard, and Peter Sheppard

2006 Archaeology in Melanesia: A case study from the western province of the Solomon Islands, in Archaeology of Oceania: Australia and the Pacific Islands: 137-159, ed. I. Lilley. Oxford: Blackwell.

Ward, Graeme K.

1979 Prehistoric Settlement and Economy of a Tropical Small Island Environment: The Banks Islands, Insular Melanesia. Ph.D. diss. Australian National University, Canberra. 
Weisler, Marshall

1997 Introduction, in Prehistoric long-distance interaction in Oceania: An interdisciplinary approach: 7-18, ed. M. Weisler. NZAA Monograph 21. Auckland: New Zealand Archaeological Association.

\title{
WICKLER, STEPHEN
}

2001 The prehistory of Buka: A stepping stone island in the northern Solomons. Terra Australis 16. Canberra: Research School of Pacific and Asian Studies, Australian National University.

\begin{abstract}
Northern Vanuatu is a significant crossroads region of the Southwest Pacific. This paper outlines current archaeological research being undertaken in the area, focusing on defining initial human settlement there some 3000 years ago and subsequent cultural transformations which led to the establishment of the ethnographic present. The study to date has contributed to a more detailed picture of inter- and intraarchipelago interaction, settlement pattern, subsistence, and cultural differentiation. The research contributes to regional debates on human colonization, patterns of social interaction, and the drivers of social change in island contexts. Keywords: Northern Vanuatu, interaction, contact and exchange, cultural transformation.
\end{abstract}

